\begin{tabular}{|c|l}
\hline Jurnal Teknologi Kimia Unimal & $\begin{array}{l}\text { Jurnal } \\
\text { Teknologi } \\
\text { Kimia } \\
\text { Unimal }\end{array}$ \\
\hline
\end{tabular}

\title{
Pembuatan Bioetanol dari Kulit Pisang Kepok dengan Cara Fermentasi menggunakan Ragi Roti
}

\author{
Syamsul Bahri*), Amri Aji, Fadlina Yani**) \\ Jurusan Teknik Kimia, Fakultas Teknik, Universitas Malikussaleh \\ *e-mail: amarul_bahari67@yahoo.com \\ **e-mail: fadlinayani231@gmail.com
}

\begin{abstract}
Abstrak
Kulit pisang kepok selama ini hanya dianggap sebagai limbah industri rumah tangga yang belum termanfaatkan dengan baik. Komponen kulit pisang terbesar adalah air dan karbohidrat, dimana karbohidrat dapat dikonversi menjadi glukosa yang selanjutnya dapat digunakan sebagai bahan baku pembuatan bioetanol. Bioetanol adalah etanol yang bahan utamanya dari tumbuhan dan umumnya menggunakan proses fermentasi. Adapun tujuan dari penelitian ini adalah mengkaji pengaruh waktu fermentasi dan volume starter terhadap bioetanol yang dihasilkan. Pada penelitian ini kulit pisang kepok dihidrolisis dengan menggunakan HCL $5 \%$ dengan suhu $100^{\circ} \mathrm{C}$ selama 90 menit, selanjutnya di tambahkan starter dengan jumlah $100 \mathrm{ml}, 200 \mathrm{ml}, 300 \mathrm{ml}, 400 \mathrm{ml}$. Kemudian di fermentasi dengan waktu 4, 6, 8, dan 10 hari. Setelah proses fermentasi selesai selanjutnya dilakukan proses penyaringan menggunakan kertas saring. Hasil yang diperoleh dimurnikan menggunakan metode distilasi. Hasil penelitian menunjukkan semakin lama waktu fermentasi dan semakin banyak starter yang digunakan maka semakin banyak etanol yang dihasilkan. Pada variasi waktu fermentasi diperoleh waktu terbaik fermentasi yaitu pada waktu 8 hari dengan volume starter $400 \mathrm{ml}$ kadar etanol yang diperoleh yaitu $67 \%$ sebanyak $35 \mathrm{ml}$.
\end{abstract}

Kata kunci: kulit pisang kepok, bioetanol, fermentasi, distilasi

\section{Pendahuluan}

Tanaman pisang kepok (Musa paradisiaca L.) merupakan tanaman dalam golongan tanaman monokotil tahunan berbentuk pohon yang tersusun atas batang semu. Batang semu ini merupakan tumpukan pelepah daun yang tersusun secara rapat dan teratur. Percabangan tanaman bertipe simpodial dengan meristem ujung memanjang dan membentuk bunga lalu buah. Bagian bawah batang pisang menggembung berupa umbi yang disebut bonggol. Pucuk lateral (sucker) muncul dari kuncup pada bonggol yang selanjutnya tumbuh menjadi tanaman pisang. Buah pisang umumnya tidak berbiji atau bersifat partenokarpi (Anonim, 2009). 


\section{Kulit Pisang}

Kulit pisang merupakan bahan buangan (limbah buah pisang) yang cukup banyak jumlahnya. Pada umumnya kulit pisang belum dimanfaatkan secara nyata dan hanya di buang sebagai limbah organik saja atau digunakan sebagai makanan ternak seperti kambing, sapi, dan kerbau. Jumlah kulit pisang yang cukup banyak akan memiliki nilai yang menguntungkan apabila bisa dimanfaatkan sebagai bahan baku pembuatan etanol, biogas, dll (Anonim, 2009). Kandungan senyawa dalam kulit pisang ditunjukkan pada Tabel 1.

Tabel 1 Kandungan Senyawa Dalam Kulit Pisang

\begin{tabular}{|l|c|}
\hline \multicolumn{1}{|c|}{ Unsur } & Komposisi (\%) \\
\hline Air & $69,80 \%$ \\
\hline Karbohidrat & $18,50 \%$ \\
\hline Lemak & $2,11 \%$ \\
\hline Protein & $715 \mathrm{mg} / 100 \mathrm{gr}$ \\
\hline Pospor & $117 \mathrm{mg} / 100 \mathrm{gr}$ \\
\hline Besi & $0,6 \mathrm{mg} / 100 \mathrm{gr}$ \\
\hline Vitamin B & $0,12 \mathrm{mg} / 100 \mathrm{gr}$ \\
\hline Vitamin C & $17,5 \mathrm{mg} / 100 \mathrm{gr}$ \\
\hline Kalsium & $0,32 \%$ \\
\hline
\end{tabular}

Sumber: (Tety, 2006).

Komponen kulit pisang terbesar adalah air dan karbohidrat. Karbohidrat dalam limbah kulit pisang dapat dimanfaatkan sebagai nutrisi pakan ternak. Seiring dengan kemajuan ilmu pengetahuan dan teknologi, kini kulit pisang dapat difermentasi menjadi bioetanol dengan bantuan Saccharomyces cereviceae.

Pati atau karbohidrat dapat diperoleh dari berbagai jenis tumbuhan seperti ketela pohon, ketela rambat, padi, pisang dan sebagainya. Di 
dalam tumbuh tumbuhan, pati disimpan dalam batang, akar, buah atau biji sebagai cadangan makanan (Agra dkk., 1973).

Klasifikasi karbohidrat terbagi menjadi 4 kelompok, yaitu monosakarida, disakarida, oligosakarida dan polisakarida.

1. Monosakarida, yaitu terdiri atas 3-6 atom $\mathrm{C}$ dan zat ini tidak dapat lagi dihidrolisis oleh larutan asam dalam air menjadi karbohidrat yang lebih sederhana. berikut macam-macam monosakarida : dengan ciri utamanya memiliki jumlah atom $\mathrm{C}$ berbeda-beda : triosa (C3), tetrosa (C4), pentosa (C5), heksosa (C6), heptosa (C7).

2. Disakarida, yaitu senyawanya terbentuk dari 2 molekul monosakarida yg sejenis atau tidak. Disakarida dapat dihidrolisis oleh larutan asam dalam air sehingga terurai menjadi 2 molekul monosakarida.

3. Oligosakarida, yaitu senyawa yang terdiri dari gabungan molekul2 monosakarida yang banyak gabungan dari 3 - 6 monosakarida,misalnya maltotriosa.

4. Polisakarida, yaitu senyawa yang terdiri dari gabungan molekul- molekul monosakarida yang banyak jumlahnya, senyawa ini bisa dihidrolisis menjadi banyak molekul monosakarida. Polisakarida merupakan jenis karbohidrat yang terdiri dari lebih 6 monosakarida dengan rantai lurus/cabang.

Ragi

Tabel 2 Komposisi Sel Saccharomyces Cerevisiae

\begin{tabular}{|c|c|c|}
\hline No & Senyawa & Jumlah (\%) \\
\hline 1 & Abu & $5,0-9,5$ \\
\hline 2 & Asam nukleat & $6,0-12,0$ \\
\hline 3 & Lemak & $2,0-6,0$ \\
\hline 4 & Nitrogen & $7,5-8,5$ \\
\hline
\end{tabular}

Sumber : Surawiria (1990). 
Ragi atau khamir adalah jamur yang terdiri dari satu sel, dan tidak membentuk hifa. Termasuk golongan jamur Ascomycotina. Reproduksi dengan membentuk tunas (budding).

Saccharomyces adalah genus dalam kerajaan jamur yang mencakup banyak jenis ragi. Saccharomyces berasal dari bahasa Latin yang berarti gula jamur. Banyak anggota dari genus ini dianggap sangat penting dalam produksi makanan. Salah satu contoh adalah Saccharomyces cerevisiae, yang digunakan dalam pembuatan anggur, roti, dan bir. Anggota lain dari genus ini termasuk Saccharomyces bayanus, digunakan dalam pembuatan anggur, dan Saccharomyces boulardii, digunakan dalam obat-obatan.

Adapun ragi yang digunakan pada penelitian ini yaitu ragi roti. Mikroorganisme ini dipilih karena ragi roti adalah Saccharomyces cerevicae yang dapat memproduksi alkohol dalam jumlah besar dan mempunyai toleransi pada kadar alkohol yang tinggi (12-18 \% abv), tahan terhadap kadar gula yang tinggi dan tetap aktif melakukan fermentasi pada suhu $4-32^{\circ} \mathrm{C}$.

Ragi roti bersifat stabil, tidak berbahaya atau menimbulkan racun, mudah di dapat dan mudah dalam pemeliharaan. Bakteri tidak banyak digunakan untuk memproduksi alkohol secara komersial, karena bakteri tidak dapat tahan pada kadar alkohol yang tinggi (Sudarmadji K., 1989).

Sel Saccharomyces berbentuk bulat telur, dengan diameter 5-10 mikrometer. Saccharomyces merupakan genus khamir/ragi/yeast yang memiliki kemampuan mengubah glukosa menjadi alkohol dan $\mathrm{CO}_{2}$. Saccharomyces merupakan mikroorganisme bersel satu, tidak berklorofil, termasuk termasuk kelompok Eumycetes. Tumbuh baik pada suhu $30{ }^{\circ} \mathrm{C}$ dan $\mathrm{pH} 4,8$. Beberapa kelebihan Saccharomyces dalam proses fermentasi yaitu mikroorganisme ini cepat berkembang biak, tahan terhadap kadar alkohol yang tinggi, tahan terhadap suhu yang tinggi, mempunyai sifat stabil dan cepat beradaptasi dengan lingkungannya (Taufik, 2012). 


\section{Hidrolisis Asam}

Hidrolisis adalah suatu proses antara reaktan dengan air agar suatu senyawa pecah terurai. Proses hidrolisa merupakan tahap penting dalam pembuatan bioetanol, karena proses hidrolisa ini menentukan jumlah glukosa yang dihasilkan untuk kemudian dilakukan fermentasi menjadi bioetanol. Prinsip hidrolisa pati adalah pemutusan rantai polimer pati menjadi unit-unit dekstrosa atau monosakarida yaitu glukosa $\left(\mathrm{C}_{6} \mathrm{H}_{12} \mathrm{O}_{6}\right)$.

Hidrolisa dengan air murni berlangsung lambat dan hasil reaksi tidak komplit, maka perlu ditambahkan katalis untuk memperbesar kereaktifan air sehingga mempercepat reaksi dan meningkatkan selektivitas. Katalisator ini bisa berupa asam maupun enzim. Katalisator asam yang biasa digunakan adalah asam klorida, asam nitrat, dan asam sulfat. Pada Industri umumnya mengunakan asam klorida sebagai katalisator.

Adapun Faktor-faktor yang mempengaruhi kecepatan reaksi pada proses hidrolisis adalah sebagai berikut:

1. Katalisator

Hampir semua reaksi hidrolisis memerlukan katalisator umtuk mempercepat jalannya reaksi. Katalisator yang dipakai dapat berupa enzim atau asam sebagai katalisator, karena kerjanya lebih cepat, pada proses hidrolisa pati biasanya digunakan asam klorida (Agra dkk, 1973).

\section{Waktu reaksi}

Untuk hidrolisis pada temperatur yang rendah biasanya dibutuhkan waktu yang lama. Dengan waktu yang lama maka hidrolisis akan semakin rata dan luas kontak permukaan antara partikel dengan cairan semakin tinggi, tetapi apabila waktu terlalu lama maka dapat mengakibatkan sebagian glukosa yang terbentuk mengalami pengurangan, waktu optimum untuk menghidrolisis pati menjadi gula berkisar 2 jam (Groggins, 1958). 


\section{Suhu}

Pengaruh suhu terhadap kecepatan reaksi mengikuti persamaan Arrhenius. Makin tinggi suhu, makin cepat jalannya reaksi. Untuk mencapai konversi tertentu diperlukan waktu sekitar 2 jam untuk menghidrolisa pati kulit pisang kepok pada suhu $100^{\circ} \mathrm{C}$. Tetapi kalau suhunya dinaikkan sampai suhu $135^{\circ} \mathrm{C}$, konversi yang sebesar itu dapat dicapai dalam 40 menit (Agra dkk,1973).

\section{Pengadukan}

Supaya zat pereaksi dapat saling bertumbukan dengan sebaik-baiknya, maka perlu adanya pencampuran. Untuk proses batch, hal ini dapat dicapai dengan bantuan pengaduk atau alat pengocok. Apabila prosesnya berupa proses alir (kontinyu), maka pencampuran dilakukan dengan cara mengatur aliran di dalam reaktor supaya berbentuk olakan (Agra dkk,1973).

5. $\mathrm{pH}$ (derajat keasaman)

$\mathrm{pH}$ merupakan faktor yang mempengaruhi proses hidrolisis sehingga dapat dihasilkan hidrolisis yang sesuai dengan yang diinginkan. $\mathrm{pH}$ yang baik untuk proses hidrolisis dengan asam adalah 2,3 (Tjokroadikoesoemo,1986).

\section{Katalis Asam Klorida}

Asam Klorida $(\mathrm{HCl})$ adalah asam monoprotik, yang berarti bahwa ia dapat berdisosiasi melepaskan satu $\mathrm{H}^{+}$hanya sekali. Dalam larutan asam klorida, $\mathrm{H}^{+}$ini bergabung dengan molekul air membentuk ion hidronium $\left(\mathrm{H}_{3} \mathrm{O}^{+}\right)$. Asam Klorida diproduksi dalam bentuk larutan $38 \% \mathrm{HCl}$ (pekat). Konsentrasi yang lebih besar dari pada $40 \%$ dimungkinkan secara kimiawi, namun laju penguapan sangatlah tinggi, sehingga penyimpanan dan penanganannya harus dilakukan dalam suhu rendah. Konsentrasi $\mathrm{HCl}$ yang paling optimal untuk pengantaran produk adalah 30\% sampai 34\%. Dari tujuh asam mineral kuat dalam kimia, asam klorida merupakan asam monoprotik yang paling sulit menjalani reaksi redoks. Ia juga merupakan asam kuat yang paling tidak berbahaya untuk ditangani dibandingkan dengan asam kuat lainnya. Walaupun asam, ia mengandung ion klorida yang tidak 
reaktif dan tidak beracun. Asam Klorida dalam konsentrasi menengah cukup stabil untuk disimpan dan terus mempertahankan konsentrasinya.

\section{Fermentasi}

Fermentasi adalah proses produksi energi dalam sel dalam keadaan anaerobik (tanpa oksigen). Secara umum, fermentasi adalah salah satu bentuk respirasi anaerobik, akan tetapi, terdapat definisi yang lebih jelas yang mendefinisikan fermentasi sebagai respirasi dalam lingkungan anaerobik dengan tanpa akseptor elektron eksternal (Muljono, 2002). Gula adalah bahan yang umum dalam fermentasi. Beberapa contoh hasil fermentasi adalah etanol, asam laktat, dan hidrogen. Akan tetapi beberapa komponen lain dapat juga dihasilkan dari fermentasi seperti asam butirat dan aseton.

Fermentasi bioetanol dapat didefenisikan sebagai proses penguraian gula menjadi bioetanol dan karbondioksida yang disebabkan enzim yang dihasilkan oleh massa sel mikroba. Perubahan yang terjadi selama proses fermentasi adalah glukosa menjadi bioetanol oleh sel-sel ragi tape dan ragi roti (Prescott and Dunn, 1959). Di dalam proses fermentasi, kapasitas mikroba untuk mengoksidasi tergantung dari jumlah aceptor electron terakhir yang dapat dipakai. Sel-sel melakukan fermentasi menggunakan enzim - enzim yang akan mengubah hasil dari reaksi oksidasi, dalam hal ini yaitu asam menjadi senyawa yang memiliki muatan positif, sehingga dapat menangkap elektron terakhir dan menghasilkan energi.

Variabel yang berpengaruh pada proses fermentasi adalah bahan baku, suhu, $\mathrm{pH}$, konsentrasi ragi, waktu fermentasi, nutrisi ragi, dan volume starter.

\section{Bahan Baku}

Pada umumnya bahan baku yang mengandung senyawa organik terutama glukosa dan pati dapat digunakan sebagai substrat dalam proses fermentasi bioetanol (Prescott and Dunn, 1959). Pada penelitian kali digunakan kulit pisang kepok sebagai bahan baku. 


\section{Suhu}

Suhu berpengaruh terhadap proses fermentasi melalui dua hal secara langsung mempengaruhi aktivitas enzim khamir dan secara langsung mempengaruhi hasil alkohol karena adanya penguapan, seperti proses biologis (enzimatik) yang lain, kecepatan fermentasi akan bertambah sesuai dengan suhu yang optimum umumnya $27-32^{\circ} \mathrm{C}$.

3. $\mathrm{pH}$

Pada umumnya $\mathrm{pH}$ untuk fermentasi dibutuhkan keasaman 3,4 - 4, ini didasari lingkungan hidup dari starter yang dapat tumbuh dan melakukan metabolisme pada $\mathrm{pH}$ tersebut (Prihandana, 2007).

\section{Konsentrasi Ragi}

Konsentrasi ragi yang diberikan pada larutan yang akan difermentasikan optimalnya adalah 2 - 4\% dari volume larutan (Dyah, 2011). Jika konsentrasi ragi yang diberikan kurang dari kadar optimal yang disarankan akan menurunkan kecepatan fermentasi karena sedikitnya massa yang akan menguraikan glukosa menjadi etanol, sedangkan maka akan dibutuhkan substrat yang lebih banyak karena substrat yang ada tidak cukup, karena itu menurunkan kecepatan fermentasi.

\section{Waktu Fermentasi}

Waktu fermentasi yang biasa dilakukan 3-14 hari. Jika waktunya terlalu cepat Saccharomyces cereviseae masih dalam masa pertumbuhan sehingga alkohol yang dihasilkan dalam jumlah sedikit dan jika terlalu lama Saccharomyces cereviseae akan mati maka alkohol yang dihasilkan tidak maksimal (Prescott and Dunn, 1959).

6. Nutrisi Ragi

Ragi memerlukan penambahan nutrisi untuk pertumbuhan dan perkembangbiakan ragi selama proses fermentasi berlangsung, misalnya : 
Unsur C : ada pada karbohidrat

Unsur N : dengan penambahan pupuk yang mengandung nitrogen, ZA, Urea

Unsur P : penambahan pupuk fosfat dari NPK, TSP, DSP, dan lain-lain.

7. Volume Starter

Penambahan volume starter yang sesuai pada proses fermentasi adalah 5\% dari volume fermentasi (Prescott and Dunn, 1959).

\section{Distilasi}

Distilasi atau penyulingan adalah suatu metode pemisahan bahan kimia berdasarkan perbedaan kecepatan atau kemudahan menguap (volatilitas) bahan atau didefinisikan juga teknik pemisahan kimia yang berdasarkan perbedaan titik didih. Dalam penyulingan, campuran zat di didihkan sehingga menguap, dan uap ini kemudian di dinginkan kembali ke dalam bentuk cairan. Zat yang memiliki titik didih lebih rendah akan menguap lebih dulu. Metode ini merupakan termasuk unit operasi kimia jenis perpindahan massa. Penerapan proses ini di dasarkan pada teori bahwa pada suatu larutan, masing-masing komponen akan menguap pada titik didihnya.

\section{Bioetanol}

Bioetanol adalah etanol yang bahan utamanya dari tumbuhan dan umumnya menggunakan proses fermentasi. Etanol atau etil alkohol $\mathrm{C}_{2} \mathrm{H}_{5} \mathrm{OH}$, merupakan cairan bening yang tidak berwarna, larut dalam air, eter, aseton, benzene, dan semua pelarut organik, memiliki bau khas alkohol serta terurai secara biologis (biodegradable), toksisitas rendah dan tidak menimbulkan polusi udara yang besar bila bocor. Etanol yang terbakar menghasilkan karbondioksida $\left(\mathrm{CO}_{2}\right)$ dan air (Skadrongautama, 2009).

Sifat-sifat kimia dan fisis ethanol sangat tergantung pada gugus hidroksil. Pada tekanan > 0,114 bar (11,5 kPa) etanol dan air dapat membentuk larutan azeotrop. Etanol banyak digunakan sebagai pelarut, germisida, minuman, bahan anti beku, bahan bakar, dan senyawa antara untuk sintesis senyawa-senyawa 
organik lainnya. Etanol sebagai pelarut banyak digunakan dalam industri farmasi, kosmetika, dan resin maupun laboratorium.

\title{
2. Metodologi Penelitian
}

\begin{abstract}
Alat
Alat-alat yang digunakan adalah pisau, blender, erlenmeyer, hot plate, neraca analitik, corong, labu ukur $500 \mathrm{ml}$, pipet volum $10 \mathrm{ml}$, beaker glass, thermometer, $\mathrm{pH}$ meter, picnometer, viskometer, alkoholmeter, sepasang alat distilasi.
\end{abstract}

\section{Bahan}

Bahan-bahan yang digunakan dalam penelitian ini adalah kulit pisang kepok, air bersih, ragi roti, pupuk NPK, pupuk Urea, aquadest, gula 500 gram, HCL 5\%, NaOH $5 \%$.

\section{Variabel Penelitian}

\section{Variabel Bebas}

1. Volume starter

: $100 \mathrm{ml}, 200 \mathrm{ml}, 300 \mathrm{ml}, 400 \mathrm{ml}$

2. Waktu fermentasi (hari) : 4 hari, 6 hari, 8 hari, 10 hari

\section{Variabel Tetap}
1. Volume sampel
: 300 gram kulit pisang/sampel
2. Suhu hidrolisis
$: 100^{\circ} \mathrm{C}$
3. Waktu hidrolisis
: 90 menit
4. Suhu distilasi
: $85^{\circ} \mathrm{C}$

\section{Variabel Terikat}

1. Yield bioetanol

2. Uji densitas bioetanol

3. Uji viskositas bioetanol

4. Kadar bioetanol 


\section{Prosedur Penelitian}

Proses pembutan pembuatan bioetanol terdiri dari beberapa tahap yaitu tahap pembuatan starter, hidrolisis, fermentasi, dan distilasi. Tahap pembuatan starter berlangsung secara anaerob dimana persiapannya yang pertama dibuat larutan gula dengan mencampurkan gula murni dengan akuades lalu dimasukkan ketempat pembiakan, selanjutnya ditambahkan pupuk urea sebanyak 10 gram dan diaduk hingga tercampur sempurna, selanjutnya ditambahkan pupuk NPK sebanyak 10 gram sambil diaduk kembali, lalu ditambahkan ragi roti sebanyak 100 gram kedalam botol, kemudian ditutup rapat dan disimpan ditempat gelap selama 24 jam. Tahapan yang kedua yaitu hidrolisis, dimana persiapannya yaitu disiapkan kulit pisang sebanyak 1000 gram kemudian dipotong kecil-kecil, kemudian kulit pisang dicuci hingga bersih dan di blender sampai halus. Selanjutnya kulit pisang direbus dengan penambahan larutan HCL 5\% sebanyak $500 \mathrm{ml}$ sampai mendidih selama 90 menit, kemudian bubur kulit pisang didinginkan sampai suhu kamar. Tahap yang ketiga yaitu fermentasi, dimana persiapannya yaitu terlebih dahulu di analisa $\mathrm{pH}$ rebusan kulit pisang untuk memastikan fermentasi dapat berlangsung dengan baik. Selanjutnya kulit pisang dimasukkan kedalam botol-botol kemudian ditambahkan starter sesuai dengan veariabel yang telah ditentukan. Kemudian campuran kulit pisang disimpan dalam ruangan gelap dengan suhu kamar selama waktu yang telah divariasikan. Tahap yang keempat yaitu distilasi dimana persiapannya yaitu larutan kulit pisang yang telah difermentasikan disaring kemudian filtratnya dimasukkan ke labu distilasi untuk dimurnikan selama 120 menit, selanjutnya uap yang dihasilkan didinginkan dengan kondenser sehingga produk yang murni tertampung dalam wadah pemisah. Produk yang diperoleh selanjutnya dianalisa dengan menghitung yield, densitas, viskositas, dan kadar bioetanol dengan menggunakan alkoholmeter.

\section{Hasil dan Pembahasan}

Penelitian ini bertujuan untuk memanfaatkan kulit pisang kepok sebagai bahan untuk menghasilkan bioetanol. Pada penelitian ini diharapkan kulit pisang 
kepok dapat menjadi bahan alternatif yang dapat digunakan sebagai pengganti minyak bumi. Bioetanol dapat digunakan sebagai bahan bakar untuk pemecahan masalah energi pada saat ini dengan cara memfermentasikan dengan ragi roti. Dari penelitian yang divariasikan adalah volume starter, dan waktu fermentasi. Adapun hasil penelitian bioetanol yang diperoleh adalah sebagai berikut:

\section{Pengaruh Waktu Fermentasi dan Volume Starter Terhadap Yield Bioetanol}

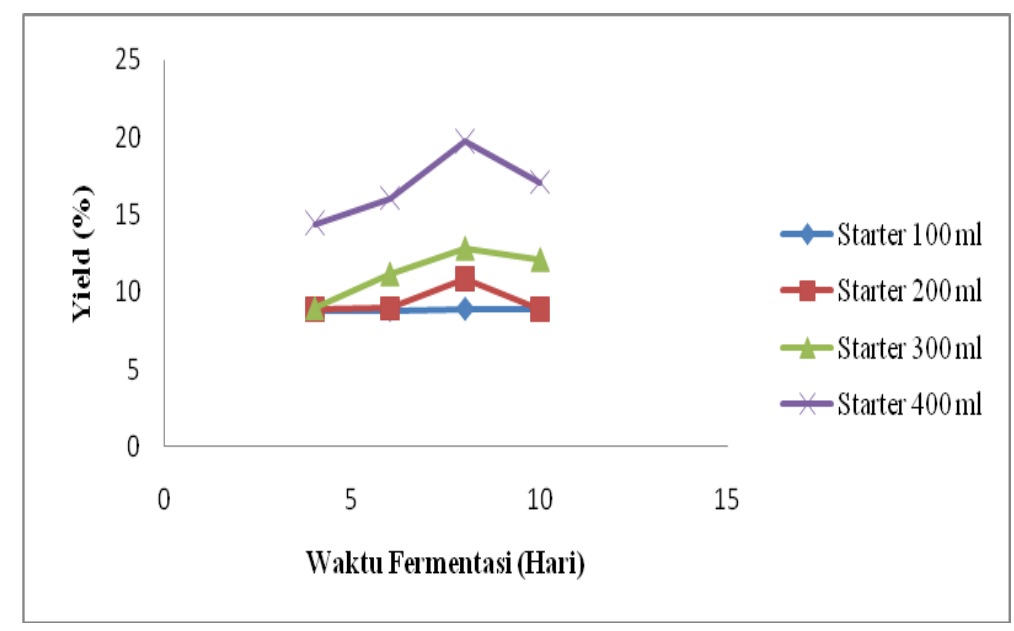

Gambar 1 Pengaruh Waktu Fermentasi dan Volume Starter terhadap Yield Bioetanol

Gambar 1 menunjukkan bahwa semakin banyak volume starter yang digunakan maka yield yang dihasilkan juga semakin meningkat. Hal ini dapat dilihat pada saat penambahan starter $300 \mathrm{ml}$ dengan waktu 6 hari yield yang dihasilkan $11,16 \%$, pada waktu 8 hari $12,83 \%$, dan terus mengalami peningkatan pada saat penambahan starter $400 \mathrm{ml}$. Pada saat penambahan starter $400 \mathrm{ml}$ dengan waktu 4 hari yield yang diperoleh 14,41\%, pada waktu 6 hari 16,04\%, pada waktu 8 hari $19,75 \%$ Hal ini disebabkan semakin lama waktu fermentasi maka etanol yang dihasilkan juga semakin banyak. Peningkatan volume starter mempercepat terjadinya fermentasi dan substrat yang ada berkadar tinggi sehingga mikroorganisme bekerja secara maksimal dalam menguraikan glukosa menjadi etanol. Namun pada saat waktu fermentasi 10 hari yield bioetanol yang dihasilkan mengalami penurunan yaitu 17,10\%. Hal ini dipengaruhi oleh pertumbuhan mikroorganisme dan nutrisi yang tersedia sudah mulai berkurang 
dan sel mulai berhenti membelah diri atau sel hidup dan sel mati mulai mencapai kesetimbangan (Tejasarwana, 1995).

\section{Pengaruh Waktu Fermentasi dan Volume Starter Terhadap Densitas Bioetanol}

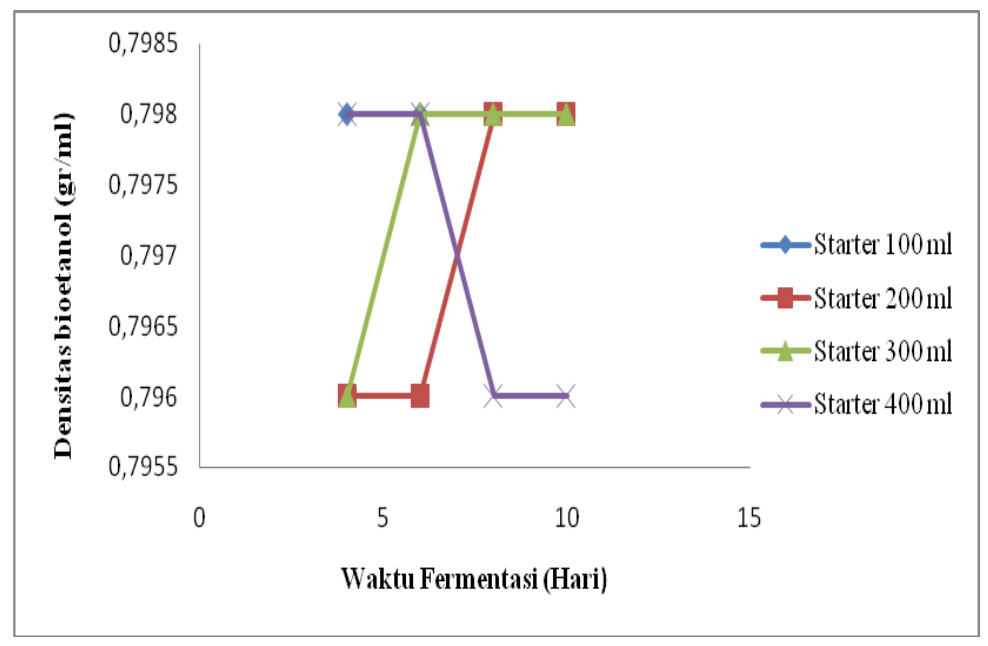

Gambar 2 Pengaruh Waktu Fermentasi dan Volume Starter terhadap Yield Bioetanol

Gambar 2 menunjukkan densitas bioetanol yang didapat semakin meningkat dengan semakin lamanya waktu fermentasi. Dimana dapat dilihat pada gambar bahwa pada saat volume starter $300 \mathrm{ml}$ dengan waktu fermentasi 4 hari densitas bioetanol yang didapat yaitu $0,796 \mathrm{gr} / \mathrm{ml}$, pada waktu fermentasi 6 hari densitas bioetanol yang didapat $0,798 \mathrm{gr} / \mathrm{ml}$, pada waktu fermentasi 8 hari densitas bioetanol yang didapat $0,798 \mathrm{gr} / \mathrm{ml}$, pada waktu fermentasi 10 hari densitas bioetanol yang didapat juga $0,798 \mathrm{gr} / \mathrm{ml}$. Hasil yang diperoleh pada penelitian ini densitas bioetanol yang didapat yaitu berada pada range 0,796-0,798 gr/ml. Dari hasil tersebut dapat disimpulkan bahwa densitas bioetanol yang didapat sesuai dan sudah memenuhi standar SNI (7390:2012), yaitu densitas bioetanol 0,798 gr/ml. 


\section{Pengaruh Waktu Fermentasi dan Volume Starter Terhadap Viskositas Bioetanol}

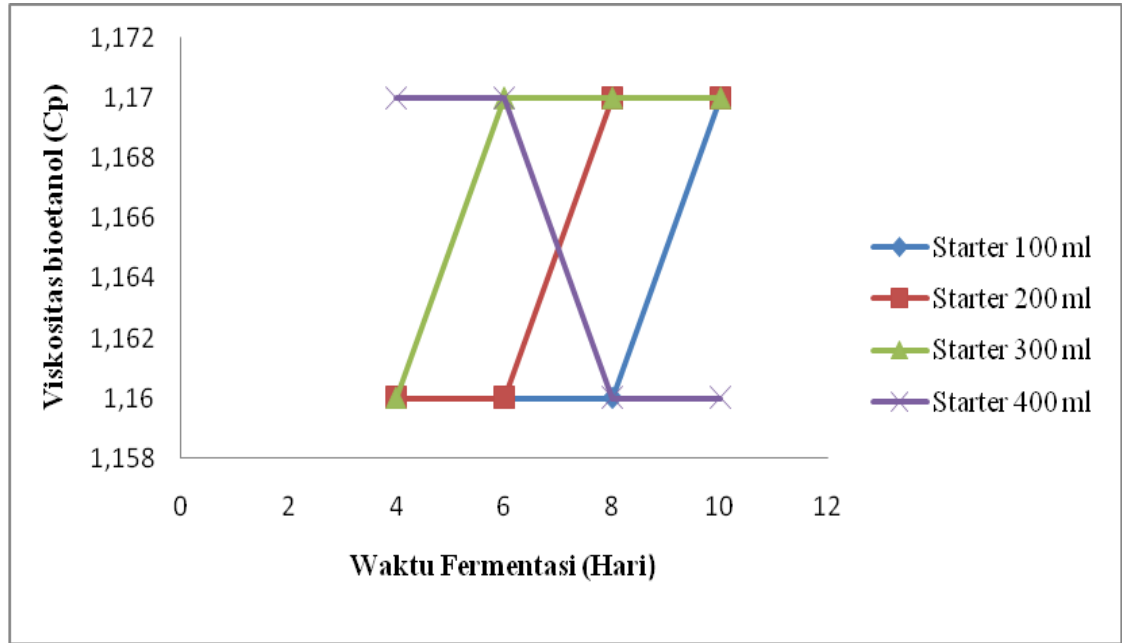

Gambar 3 Grafik Pengaruh Waktu Fermentasi dan Volume Starter terhadap Viskositas Bioetanol

Gambar 3 menunjukkan bahwa viskositas bioetanol (kekentalan bioetanol) sangat dipengaruhi oleh waktu fermentasi dan banyaknya starter yang digunakan. Dimana dapat dilihat pada gambar bahwa pada saat volume starter $100 \mathrm{ml}$ dengan waktu fermentasi 4 hari viskositas bioetanol yang didapat yaitu 1,16 $\mathrm{Cp}$, pada waktu fermentasi 6 hari viskositas bioetanol yang diperoleh $1,17 \mathrm{Cp}$, pada waktu fermentasi 8 hari viskositas bioetanol yang didapat $1,17 \mathrm{Cp}$, pada waktu fermentasi 10 hari viskositas bioetanol yang didapat juga 1,17 Cp. Pada saat volume starter dinaikkan menjadi $200 \mathrm{ml}, 300$, dan $400 \mathrm{ml}$, viskositas bioetanol yang diperoleh berada pada range 1,16-1,17 Cp. Hal ini menunjukkan bahwa viskositas bioetanol yang didapat sudah memenuhi standar bioetanol SNI (7390:2012), yaitu viskositas bioetanol 1,17 Cp.

\section{Pengaruh Waktu Fermentasi dan Volume Starter Terhadap Kadar Bioetanol}

Gambar 4 menunjukkan bahwa semakin lama waktu fermentasi dan semakin banyak volume starter maka kadar bioetanol yang dihasilkan semakin meningkat. Dimana dapat dilihat dari gambar bahwa pada waktu 4 hari dengan volume starter $100 \mathrm{ml}$ bioetanol sudah terbentuk dengar kadar 32\%, dan terus bertambah pada hari ke 6 menjadi 34\%, pada hari ke 8 menjadi 37\%. Pada waktu 
8 hari dengan volume starter $300 \mathrm{ml}$ bioetanol yang terbentuk semakin tinggi yaitu 57\%. Tetapi pada waktu fermentasi 10 hari mengalami penurunan terhadap kadar bioetanol walaupun starter yang ditambahkan semakin banyak. Hal ini disebabkan konsentrasi nutrient mulai berkurang maka pertumbuhan mikroba mulai menurun sampai pertumbuhan mikroorganisme nol, fase ini disebut juga fase stasioner (Said, 1987).

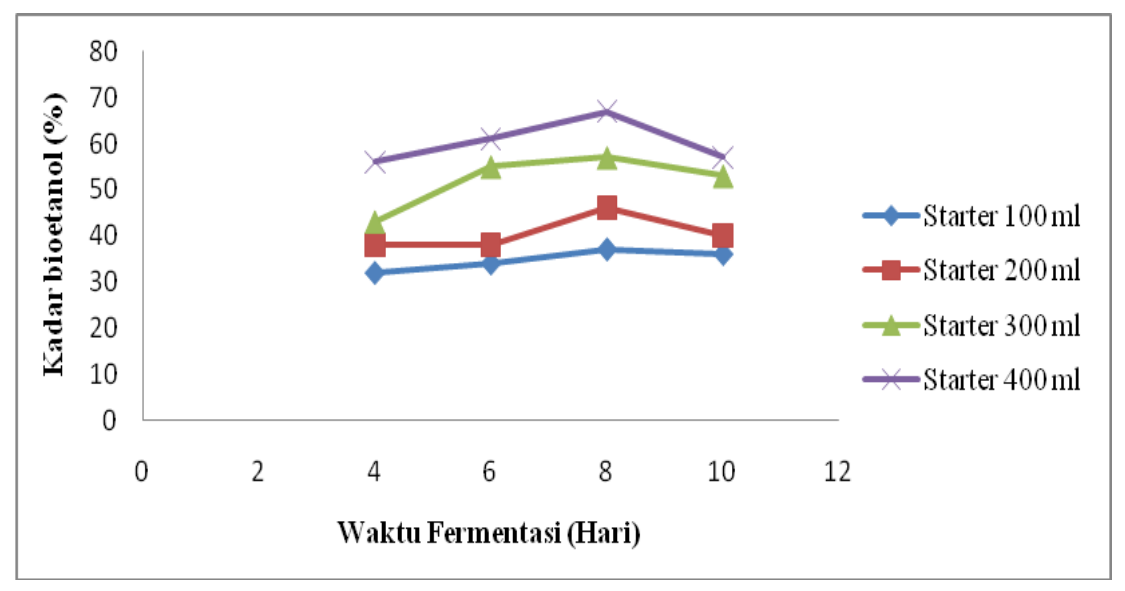

Gambar 4 Grafik pengaruh waktu fermentasi dan volume starter terhadap kadar bioetanol

\section{Kesimpulan}

Berdasarkan hasil dan pembahasan dapat diambil kesimpulan sebagai berikut:

1. Semakin lama waktu fermentasi maka bioetanol yang dihasilkan semakin banyak.

2. Semakin tinggi volume starter maka bioetanol yang didapat semakin banyak.

3. Peningkatan volume starter akan mempercepat terjadinya proses fermentasi.

4. Kadar bioetanol terbaik didapatkan pada saat penambahan starter $400 \mathrm{ml}$ dengan waktu fermentasi 8 hari.

5. Densitas bioetanol yang didapat berada pada range $0,796-0,798 \mathrm{gr} / \mathrm{ml}$ dan sesuai dengan standar SNI. 


\section{Daftar Pustaka}

Anonim, 2009. Kulit Pisang. Online di http://www.scribd.com. Diakses 13 September 2017.

Agra, dkk. 1973. Hidrolisa Pati Ketela Rambat. Forum Teknik.115-129.

Dyah. 2011. Pembuatan Bioetanol dari Kulit Pisang. Prosiding Seminar Nasional Teknik Kimia “Kejuangan”, Jurusan Teknik Kimia, FTI UPN”Veteran”. Yogyakarta.

Groggins, P. H., 1958. Alcohols Their Chemistry Properties and Manufacture, Reinhold Book Corporation, New York.

Muljono, Judoamidjojo, Darwis, Aziz, A., dan Gumbira, E. 2002. Teknologi Fermentasi. Rajawali pers: Jakarta.

Prescott, S.C., Dunn. 1959. Industrial Microbiology. New York: MC Grow Hill Book Company.

Prihandana, R., K. Noerwijati (dkk). 2007. Bioetanol Ubi Kayu Bahan Bakar Masa Depan. Agromedia Pustaka. Jakarta.

Sudarmadji, S., Haryoo, B., dan Suhardi. 1989. Prosedur analisa untuk bahan makanan dan pertanian. Edisi ketiga. Yogyakarta: Liberty.

Skadrongautama, 2009. Bahan Bakar Nabati (Bioetanol). Yogyakarta: Khalifah Niaga Antabura.

Suriawiria,U. 1990. Pengantar Biologi Umum. Penerbit angkasa. Bandung.

Tjokroadikoesoemo, P. Soebijanto, 1986. HFS dan Industri Ubi Kayu Lainnya. PT Gramedia: Jakarta.

Tety, 2Kandungan kulit pisang. Online di www.risvak.com/reaksi bioetanol.

Diakses pada 15 September 2017.

Taufik, Ardiyanto. 2012. Tentang Jamur Ragi.Online.(Diakses http://www.Taufik Ardiyanto. Blogspot.com. Akses 15 Februari 2018. 